\title{
Impact of Demographic Factors on Consumer's Purchasing Decision: A Study on the University Students of Peshawar Region
}

\author{
IHSAN ULLAH \\ Lecturer in Marketing, The University of Agriculture Peshawar, \\ ihsanullahmit@gmail.com \\ SALEEM ULLAH KHAN \\ Lecturer in Marketing, The University of Agriculture Peshawar, \\ salimullahmarwat@hotmail.com \\ MUHAMMAD IDREES \\ Lecturer in Computer Science, The University of Agriculture Peshawar, \\ muhammad.idrees@aup.edu.pk
}

\begin{abstract}
This research report is based on the factors affecting the purchasing decision of the students (consumers) of various public and private sector universities in Peshawar (Pakistan). The main objective of this study was to find out the impact of demographic factors such as gender, age and income on consumers purchasing decision. In this study the population was students of various private and public sector universities of Peshawar region. A sample of 250 students was drawn from population through proportionate random sampling technique. A questionnaire was designed and personally distributed among the subjects of sample. Independent samples T-test and ANOVA were used for data analysis. The findings lead to the conclusion that there is no significant relationship between consumers' gender and age with purchasing decision while income of consumers significantly affects their purchasing decision.
\end{abstract}

Keywords: Gender, Age, Monthly Income, Consumer's Purchasing Decision

\section{Introduction}

A consumer is someone who buys goods or services for personal use, can make the decision whether or not to buy an item at the outlet, and someone who can be influenced by marketing stimuli (Kotler and Arm Strong, 2000). As individuals, we are all different. Although one of the most significant constant among all of us, regardless of our dissimilarities, is that, we are consumers. We consume or use on a regular basis food, clothing, shelter, transportation, education, luxuries, services and even ideas. As consumers, we play a very important role in the wellbeing of economy (Schiffman \& Kanuk, 2012). Zhang (2007) established that there is a conventional theoretical structure for the buyer purchasing decision. Since 1960s this structure is the mainly distinguished model for purchasing decision. This model consists of 5 phases. According to Solomon (2007), need identification occurs when the buyer perceived a huge gap between his current states and some ideal state. She or he feels that there is an unfulfilled need to be satisfied, which might be complex or easy. 
After realizing the need, the buyer studies the surroundings for suitable information to arrive on a rational choice. Although, the data search of the consumer could be cut off into two phases. Inside search originates from buyer previous knowledge, culture, and every one of buyers will have their very individual level of learning regarding the item in their recall. Outer search initiates from marketer overwhelm sources or information to consumer by means of commercial, friends, business sites and sales representatives. At the evaluation of alternatives of buying decision the buyer will have to do hard work in terms of assessing alternatives. It implies that, buyer will look at the few items in the outlet on their reputation, merits and demerits. At the stage of purchase decision, the customer may make a selection of item from available product alternatives. Post-purchase behavior is the last condition of purchasing process that occurs as the consumer purchase the item and begins to utilize. The consumer may or may not be satisfied would often depends on his/her prior established expectations from the product's performance and product's perceived performance. Purchasing process is a vital model for any individual who making marketing plans. In this way, the marketers have to understand the customer behavior or whole purchasing procedure as compared to focus just purchase decision ,because if we center just around purchase decision, sometimes it is probably late for the business to influence the purchase decision (Solomon, 2007).

Buying decision is one of those activities that individuals make in their daily lives. Consumers make many buying decisions every day. Many marketers do research buying decisions to know about what consumers buy, where they buy, how and how much they buy, when they buy and why they buy. In addition to marketing and environmental stimuli consumers buying decisions are also be influenced by consumers' demographic factors such as gender, age, income, and education (Kotler and Armstrong, 2000). Individuals can settle on choices on numerous things. Theories on the buying behavior of consumers are persistently being analyzed by organizations to develop strategies that how to influence and persuade the consumer to purchase their products. Actually a consumer first recognizes a need and pursues a sequence of steps prior to settle on the buy decision. Although, different buyers will arrive on different purchasing decisions due to various issues like environmental, demographical and cultural influences and even their individual personalities. The consumers buying decision is supported by various consumers buying behavior theories of learning(operant conditioning, cognitive) and Maslow's needs hierarchy theory of motivation (Kotler \& Armstrong, 2000).

Purchasing decision refers to the decision that a person makes for buying a product. This term can also be explained with the help of consumer purchasing decision process, which consist of certain steps carried out by a consumer for the purchase of a product. In the context of marketing this term has gain enormous popularity and attention because the modern marketing concepts try their best to motivate consumer's demand and finally their actual purchase action. A considerable number of researches have been published about purchase decision and demographics (Saleh, Alothman \& Alhoshan 2013). According to Akturan (as cited by Bakshi, 2012) out of the considerable number of factors that impact consumers buying decision, since one of them is the demographical factors. It has a vital place in customer behavior. For the reason that, the differences of demography means differences in expectations, want, need, life-style and spending behaviors. The decision makers may be divided on the basis of gender into male and female. In this fashion, when there is a sex distinction, 
the perception of purchasing and expending the item additionally vary. Moreover, the components that can impact male and female buying choices are likewise distinctive. For instance to purchase an automobile men give emphasis on the engine and fuel consumption of the automobile, whereas women may emphasize on the color, design and other features of the automobile (Business Thai, 2004). Hence one can say that, the purchase decision making may differ due to gender, regardless of the product that the buyer is going to buy (Sidin, Zawawi, Wong, Busu, \& Hamzah, 2004). Consumer's behaviors can also be change due to different other factors such as economic development of society, level of education, increase in income or the size of family (Sidin, Zawawi, Wong, Busu, \& Hamzah, 2004), (as cited by Plabdaeng, 2010).

Individuals are exposed to several sources of information and huge varieties of products with many deals of options frequently available in the market impulse their buying decisions even so the analysis and process of decision making vary from person to person and gender to gender (Michael and Solomon, 1994). Female is more influenced by the environment, get extra information, as well as give extra time to the purchase decision procedure (Gill, Stockyard, Johnson, \& Williams, 1987). In contrast male are utmost objective, practical, leading and self-confident (Wood, 1990). According to Doston (2011) age of consumers also affects their purchasing decision. Age differences influence consumer's product/brand choices. Old age people are more loyal with brand and store (East, Harris, Willson \& Lomax, 1995).

Income is consumers' that money that they get from all their sources. Income not only influences product/ brand, store choices but also quantity of product/brand to be purchased (Hast, 1997).

\subsection{Research Problem}

Our main research problem is to analyze "The impact of demographic factors on purchasing decision of the students of various public and private universities in Peshawar Region".

\subsection{Objectives of the Study}

The current study is intended to find out the impact of demographic factors such as gender, age, and income on consumer's purchasing decision. The more specific objectives of this study are:

- To identify that Gender of consumers significantly affect their purchasing decision.

- To know that Age of consumers significantly affect their purchasing decision.

- To know that Income of consumer significantly affect their purchasing decision.

\subsection{Purpose of the Study}

This study will give a thorough discussion of demographic factors and their relationship with consumer buying decision. The results of this research will be very helpful for the readers to decide whether or not demographical factors affect consumer's decision making. The current study will be a good contribution to the existing literature because the study is specifically to the segment of Peshawar Region, and also the study will represent the mindset of the individuals of Peshawar. 


\section{Literature Review}

\subsection{Introduction}

This chapter describes the review of literature as presented by other researchers and authors in the same field of purchasing decision. The various sections presented here are, concept of purchasing decision, hierarchical theory of needs, factors influencing purchasing decision of final consumer and the theoretical framework to the study.

\subsection{Purchasing Decision}

Purchasing decision refers to the decision that a person makes for buying a product. This term can also be explained with the help of consumer purchasing decision process, which consist of certain steps carried out by a consumer for the purchase of a product (Saleh, Alothman \& Alhoshan 2013). Lascu and Zinkhan; and Chen-Yu and Soak (as cited by Kakiza, 2015) noted that " buying decision is the procedure whereby an individual as an ultimate consumer recognize a specific product to the spot of exchanging it with money after accepting its features such as quality, amount and utility.

\subsubsection{Stages Involved in Purchasing Decision}

Five stages are involved in consumer purchasing decisions which are discussed below.

\subsubsection{Need Recognition and Problem Awareness}

The purchasing process starts with problem or need identification where the buyer perceives an issue or need.

\subsubsection{Information Search}

An interested purchaser might probably look for further inputs. Customers can acquire data from individual, business and other means or sources.

\subsubsection{Evaluation/Assessment of Product or Brand Alternatives}

In this phase the buyer utilizes information to assess product/brand alternatives (Kotler, 2011).

\subsubsection{Purchase Decision}

In the assessment phase, the customer ranks brands and shape purchase intention. By and large, the buyer's buy choice possibly will be to purchase the most favored brand, yet two situations can separate the buy aim and the buy decision. The first situation is the other peoples' attitude and another is unforeseen situational factors (Kotler, 2011).

\subsubsection{Post-Purchase Behavior}

The marketer's activity does not finish when the item is purchased. Subsequent to obtaining the item, the buyer will either be satisfied or disappointed and will involve him or her in post buy behavior that is very important for the marketer. In the context of marketing the term purchasing decision has gain enormous popularity and attention because the modern marketing concepts try their best to motivate consumer's demand and finally their actual purchase action. A considerable number of researches have been published about purchase decision and demographic (Saleh, Alothman \& Alhoshan, 2013). Motivation is the process that guides individuals to act as they do. It occurs when a need is triggered that the individual wishes to satisfy. Once a need has been enacted a situation of stress exists that forces the individual to lessen or wipe out the need (Plabdaeng, 2010). Be that as it may, the most important theory of motivation that is utilized by the notable and numerous marketers for developing marketing strategies were proposed by the Psychologist Abraham Maslow. Maslow distinguished the needs of human into biogenic need and psychogenic need. These 
both types of needs form needs hierarchy that indicates definite dimensions of motives. Imply that, the dimension of needs in each category will be achieved prior to the subsequent dimension then the more elevated amount of need is initiated. The five levels of needs are the base of Maslow's hierarchy of needs, arranged according to the level of importance. Maslow's five levels/categories of needs are: 1 . Biological needs 2. Safety and security needs 3. Social needs 4. Esteem needs 5.Self-actualization needs. Physiological and Safety needs are lower order needs, while Social, Esteem, and Self-actualization/completion needs are higher order needs (Kotler, 2011). These five levels of needs are likewise diagrammatically depicted in figure No 2.1.

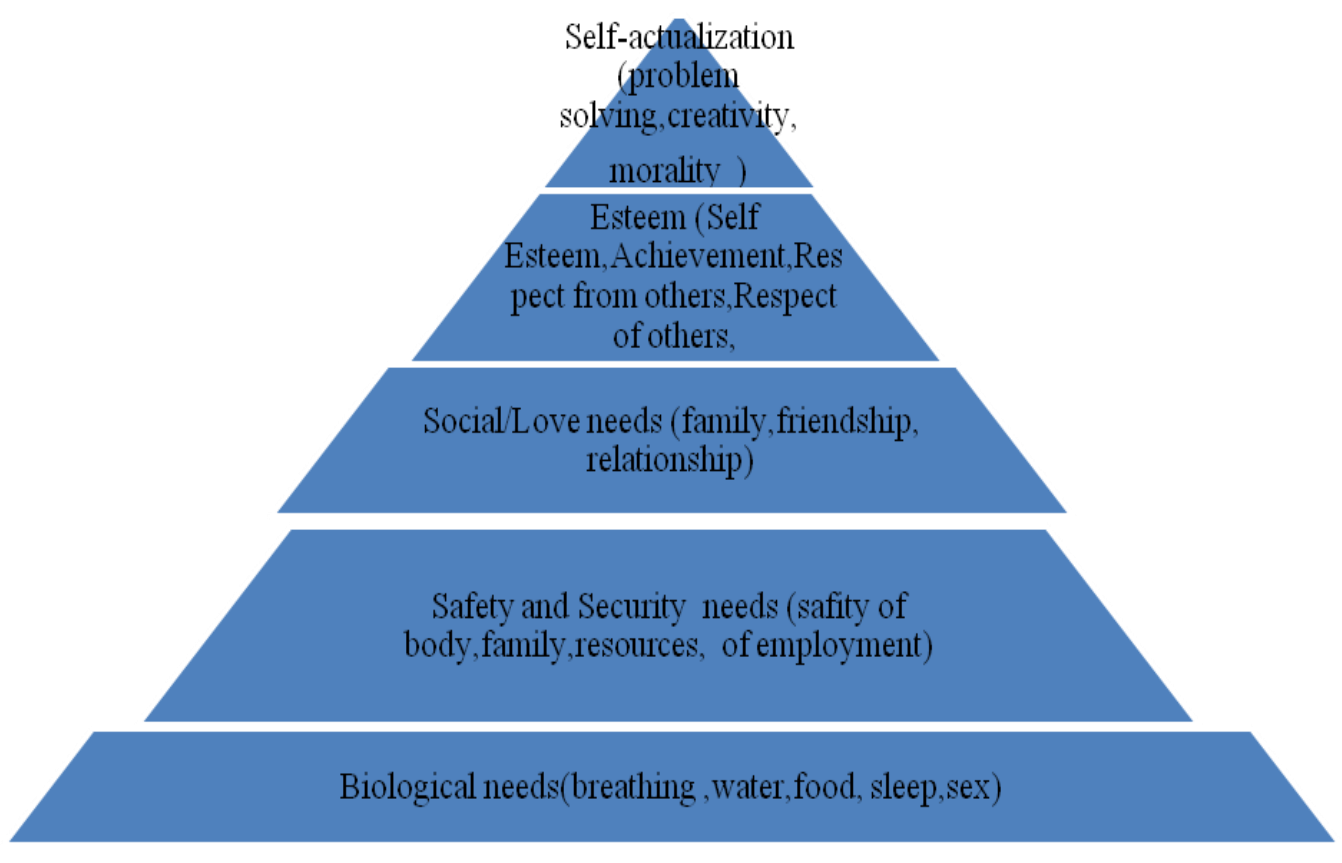

Figure 2.1 Schematic Diagram of Maslow's Hierarchical Theory of Needs

\subsubsection{Hierarchical Theory of Needs and Purchasing Decision}

The initial phase in customer buying process is the need acknowledgment or inspiration/motivation, where customers understand that she/he has requirement for something. Customers' requirement for uniqueness is symbolic as it drives consumption decision about how she/he shows her/his personal identity. Accomplishment, status, association and having a place are emblematic on the grounds that they reflect consumers"e social position or responsibility (Kakiza, 2015). Consumers use most of their resources to satisfy lower order needs earlier than the higher order needs become meaningful. Marketing programs require a knowhow of which motives drive given product options. Advertising etc. can demonstrate how a product or brand satisfies these needs.

\subsection{Demographic Effects}

Do demographics assume a part in consumers' purchasing choices? Past and ebb and flow inquires about in view of behavioral sciences have concentrated on the demographics. Sharma and Antil (2013) have investigated the effects of sexual orientation, age, wage and size of family on purchasers' purchasing decisions. 
Consequently, it has been seen that these elements have a solid association with buyer's purchasing choices. Let's get a detailed discussion of each of these factors in the following lines. Consumer behavior might be influenced by numerous factors. It might be distinct from individual to individual due to his age, gender, income etc. Anyone can simply observe the distinction between the purchasing decisions of two dissimilar individuals from dissimilar economic groups (Pratap, 2017).

\subsubsection{Gender}

In addition to the considerable number of components that impact buyers' purchasing decision, one is the sexual orientation. It shows the social responsibilities, duties and relationship of males and females, the desires detained about the qualities, skills and likely practices of both men and women (masculinity as well as femininity), that are adopted through learning, and change after some time and fluctuate inside and between societies. As indicated by Mitchell and Walsh (2004), men and women require different items and both genders are probably going to have unique methods for loving and getting these. Sexual orientation has a significant position in customer behavior. As indicated by Solomon (2007), a critical part of a buyer's self idea is sexual makeup. Sexual individuality can typify a sex into (male and female.The procedure of making purchase decision has been examined for such a long time with the responsibilities of husband and wife, and item (Henthorne, La Tour, and Hudson, 1997). As indicated by Sidin, Zawawi, Wong, Busu, and Hamzah, that sexual orientation is encompassing standards that strengthen the relationships among male and female. In addition, family could be deemed as a fundamental unit of purchase decision making process.

Livette (2007), contended that at some point the regard between various sexes will change because of the change in role of the general public by this reason thoughts of a couple may be different and at that point clashes will happen. Livette (2007) likewise referenced that men and women may have diverse choices when settling on the buy choice. Men will concentrate more on definite decisions or assignments however females will concentrate more on their exercises. Females are no doubt influenced by the compassion however males are nearly all be impacted by comprehension (Livette, 2006).According to Solomon (1999) in the past marketers believe that men take the key decision of buying car, however in the late1990 more than 6 out of 10 new automobiles were purchased by women of age below 50 years.

\subsubsection{Age}

According to Pratap (2017), age is an essential variable that manipulates buyer behavior. As people grow, their requirements alter. Relative adjustments come in their purchase decision making. With changes in age, our health requirements changes thus do numerous other needs. Age put across changes to people lifestyle and with it their requirements and personal values are likewise affected. At the time when people are young, they expend extra on their lifestyle needs from amusement and motion pictures to fashion. As they get older, their expenditures on these stuffs reduce. Older individuals for the most part stay indoors; in any case, their health connected costs may rise. Along these lines, age turn out to be the key demographic variable influencing buyer behavior and purchasing decisions.

Age doesn't simply influence purchasing conduct; it is likewise a vital factor influencing marketing decisions. Age is used as a base by marketers to segment their markets (Pratap, 2017). How older adults settle on choices and develop their choice options is of significance to understanding buyer decision making. More seasoned 
individuals have been appeared to incline toward buying brands that have been built up for an extended time (Lambert-Pandraud, Laurent, Lapersonne, 2005). This is to be expected because of various reasons, including experience and connection with items, sentimentality, propensity, and conceivable abhorrence for change (LambertPandraud, Laurent, 2010).

Hunting down new information is psychologically burdening practice, and older people will in general take part in less of it when deciding. When making consumption decision, more seasoned individuals will in general tend to build slighter consideration sets, (Lambert-Pandraud, Laurent, Lapersonne, 2005) which is an immediate after effect of their constrained time spent exploration for various brands' information (Johnson, 1990). This decrease in choice consideration set level is placed to be the consequence of a "shrinkage" effect, whereby the decline in information searched for and acquired likewise prompt the consideration of a little amount of options (Lambert-Pandraud, Laurent, 2010). Other research shows that more seasoned individuals are bound to take part in repeat buying, particularly when their considered set of options are smaller (Lambert-Pandraud, Laurent, \& Lapersonne 2005).More seasoned persons arrive on a buying choice based on experience and judgment of fulfillment which they perceive by using the product, anyway the young people don't depend on the fulfillment which they perceive from the product; they furthermore get inputs from the sales people and subsequently arrive on a conclusive buying choice (Homburg, 2001). The need and tendencies of the shoppers have been changed with the passage of time, young people expend on drive-thru food typically and elder persons expend on the products known for their wellbeing (Solomon, 1999).

\subsubsection{Monthly Income}

Income signifies the money which individuals and households acquire from all sources; it is the most vital demographical feature that considerably influences spending of the customers, selection of the retail outlet and their sales quantity as well (Homburg, 2001).Income is a critical factor that influences the purchasing decisions and behavior of individuals. The income level of an individual determines what sort of items he/she routinely buys. Higher disposable incomes of individuals will allow them to spend more on lifestyle or luxury items. Such individuals likewise expend more on tours and vacations. After sales support and customer service become significant aspects with regards to first-class buys (Pratap, 2017).

\subsection{Theoretical Framework}

The foundation on which the entire research project is based is known as theoretical framework. Theoretical framework is a reasonably developed illustrated and detailed arrangement of associations amongst the important variables considered pertinent to the problem situation and which have been discovered through the processes of observations, interview and literature survey. It is made out clear at this stage that to find solution to the problem one should first recognize the problem and next identify the variables that contribute to it (Sekaran, 2003). In the current study the dependent variable is consumer's purchasing decision, which is the variable of primary interest to the researcher, the variance in which is attempted to be explained by the three independent variables of (1) gender of consumers (2) age of consumers, and (3) income of consumers. The figure No.2.2 diagrammatically describes the theoretical framework. 


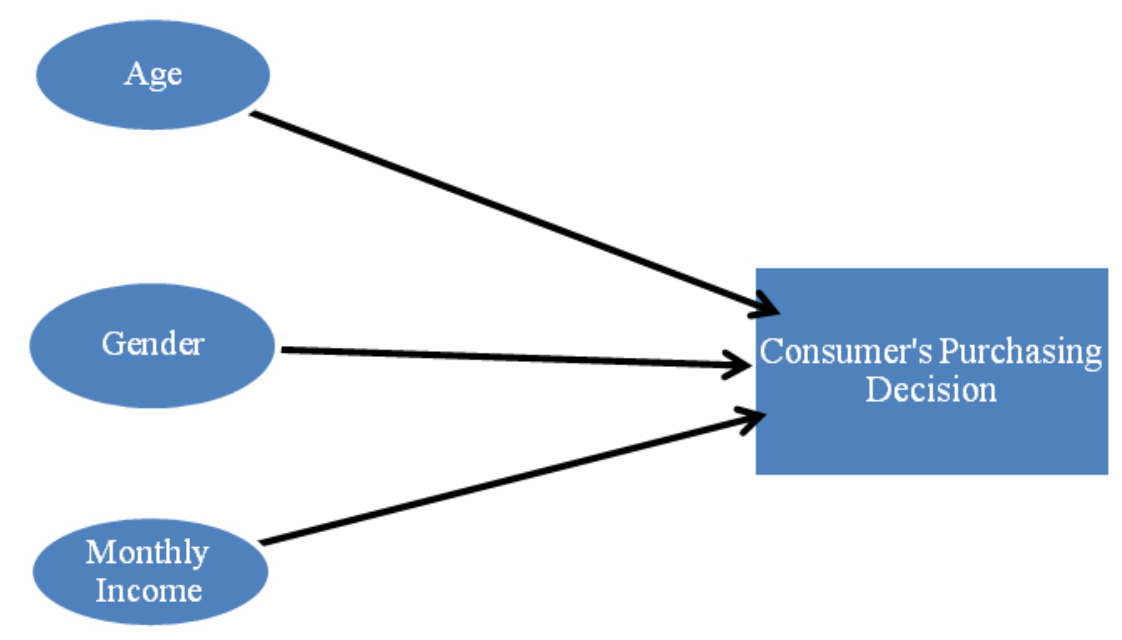

Figure 2.2 Schematic Diagram of Theoretical Framework

\subsection{Hypotheses of the Study}

In the current study the following hypothesis were formulated and tested to conclude whether the relationships that have been theorized do in fact, hold true.

- There is a significant difference in purchasing decision of males and females students.

- There is a significant difference in purchasing decisions of different age groups of students.

- There is a significant difference in purchasing decisions of different monthly income groups of students

\section{Research Methodology}

\subsection{Introduction}

The current chapter explains the methodology employed in the current research study. The subjects in this part are research design, population of the study, unit of analysis, the sampling design, sources of information, how the data will be collected (data collection instrument), how variables will be measured (measurement) and how the data will be analyzed (data analysis), (Sekaran, 2003).

\subsection{Research Design}

A framework for the collection and analysis of data is called research design (Bryman and Bell, 2003). For Gathering data to answer questions concerning this study a descriptive survey research design is utilized. Descriptive study includes collecting data that exposed events and after that put in order, tabulates, delineate and depicts the data accumulation (Glass and Hopkins 1984).This plan is supported in light of the fact that it relates the quantitative thoughts of a study sample. Moreover the research design by the virtue of being cross-sectional gives a description of the entire population with the minimum bias. A descriptive research study looks to find out answers to who, when, where and how of research question which is the focal point of the current study.

\subsection{Target Population}

The target population of this survey is only incorporated the students of the department of management sciences of the public and private sector universities in 
the Peshawar region. The total numbers of students in all these universities are almost 5680. Table 1 provides the necessary information about these universities.

Table 1: Names of Public and Private Sector Universities in Peshawar Region

\begin{tabular}{|c|c|c|c|}
\hline S. & University & Region & URL \\
\hline 1. & The University of Agriculture & Peshawar & www.aup.edu.pk \\
\hline 2. & $\begin{array}{c}\text { Institute of Management } \\
\text { Sciences }\end{array}$ & Peshawar & www.imsciences.edu.pk \\
\hline $\begin{array}{c}3 . \\
4\end{array}$ & CECOS University & Peshawar & $\underline{\text { www.cecos.edu.pk }}$ \\
\hline 4. & Qurtaba University & Peshawar & www.qurtuba.edu.pk \\
\hline
\end{tabular}

\subsection{Unit of Analysis}

The current study focused on recognizing the relationship between age, gender, and income, with purchase decision of the students of management sciences. Accordingly, the unit of analysis is the students of the management sciences departments.

\subsection{Sampling Design}

According to Roscoe (as cited by sekaran, 2006), as a popular principle, for the majority of research is, to select sample sizes between 30 and 500 are suitable, and where categories (males/females, etc.) are involved in a study, for every category a sample size of at least 30 is necessary. Due to the time, and financial constraints, for the current study top four universities (According to HEC 2016 report) of Peshawar have been selected as a population and subsequently a sample of 250 students was selected from top four universities by using a proportionate simple random sampling method (Cochran, 1977). For ease, the proportionate method is explained as:

$n_{i}=\frac{n}{N} \times N_{i}$

Where,

$n=$ the needed sample size selected from the population

$N$ indicates population size

$N_{i}=$ number of students of in each university

$n_{i}=$ number of students selected from each university.

Table 3.2 shows the number of students selected from each university by proportionate method.

Table 2: Number of Mgt.Sciences' Students in the Selected Universities

\begin{tabular}{llll}
\hline S.No. & Name of University & $\begin{array}{l}\text { Total } \\
\text { Students }\end{array}$ & Sample \\
\hline 1 & The University of Agriculture & 2100 & 70 \\
2 & Institute of Management Sciences & 2200 & 80 \\
3 & CECOS University & 850 & 60 \\
4 & Qurtaba University Peshawar & 530 & 40 \\
Total & & $\mathbf{5 6 8 0}$ & $\mathbf{2 5 0}$ \\
\hline
\end{tabular}

Source: University administration (Establishment section) 
Proportionate random sampling method has been employed for the current study. This approach has been implemented in each university as to reduce bias thereby. The population for current study includes all business students of aforementioned four universities. The number of students provided by the concerned departments of each university is produced in above table 2 .

Table 3: Detail of the research questionnaires sent and corresponding responses

\section{Questionnaires}

\begin{tabular}{lllllc}
\hline \# & University Name & Campus & \multicolumn{2}{c}{ Sent } & \multicolumn{2}{c}{ Received\%age } \\
\hline 1. Agriculture University Peshawar & Main & 70 & 55 & $79 \%$ \\
2. Institute of Management Sciences & Main & 80 & 68 & $85 \%$ \\
3. CECOS University Peshawar & Main & 60 & 27 & $45 \%$ \\
4. Qurtaba University Peshawar & Main & 40 & 23 & $64 \%$ \\
$\quad$ Total & & $\mathbf{2 5 0}$ & $\mathbf{1 7 3}$ & $\mathbf{6 9 \%}$
\end{tabular}

3.6 Sources of information

Primary data have been employed for analysis of the data.

3.6.1 Primary data

As indicated by Sekaran (2006) the data which is collected for investigation from the genuine place where events are occurring, called master data. For the purpose to address the research objectives the current study is based on primary data.

\subsection{Data Collection Instrument (Questionnaire)}

To have more logical approaching to the question under consideration a researcher needs solid instructions which facilitate the proper structuring of the inquiry. One of them is a research questionnaire. In addition, a researcher is also guided by other research expertise (Dhanapal, et al., 2013; Khan, et al., 2012). For this survey, a structured questionnaire was utilized for data collection, which includes 18 items. The respondents have been endowed with the options to grade their answers on a 5-point Likert scale ( $1=$ Strongly Disagree, to $5=$ Strongly Agree).As mentioned below:

\begin{tabular}{ccccc}
\hline Strongly Disagree & Disagree & Undecided & Agree & Strongly Agree \\
\hline 1 & 2 & 3 & 4 & 5 \\
\hline
\end{tabular}

\subsection{Measurement}

To measure the variables of interest 2 scales (Nominal and Interval) have been employed for the current work.

\subsection{Data Analysis}

Data analysis refers to examining what has been collected in a survey or experiment and making deductions and inferences (Kombo \& Tromp, 2006). The filled questionnaires were subjected to software known as statistical package for social sciences (SPSS) by performing T-test and one way ANOVA in order to get more reliable results. It is widely used package for data analysis. 


\section{Results and Discussion \\ 4.1 Introduction}

The results and discussions are considered the main stay of this bodily function in conducting research. It makes the research more systematic, interpretable, presentable, generalize, precise, conclusive and academic. This section provides the detail of data of analysis. The SPPS version 20 was used for analysis of the data. This chapter includes demographic information of the respondents, reliability and descriptive analysis exercised to evaluate the criteria, independent samples T-Test and One Way ANOVA have been discussed for hypothesis testing and. The last section of this chapter provides detail of conclusion, recommendations, limitations and directions for future research.

\subsection{Sample Characteristics and Descriptive Statistics}

A total of 250 survey questionnaires were distributed among the students of the department of Management Sciences in various universities (such as The University of Agriculture, Qurtaba University, CECOS University, and Institute Of Management Science) at Peshawar. In response a total of 173 students returned the questionnaires. This demonstrated a response rate of 69\%.All the returned questionnaires were found properly filled in and were found suitable for statistical analysis. Various frequency tables are presented in the coming pages.

\subsection{Demographic Information of the Respondents}

Gender information of the respondents includes the following.

\subsubsection{Gender of the Respondents}

Table 4 shows the details about gender of the respondents. The table that represents the majority of the students are male i.e. $n=99$, consists of about $57 \%$, on the other hand the female students are 74 , about $42 \%$.

Table 4: Gender of the respondents

\begin{tabular}{llllll}
\hline & & Frequency & Percent & Valid Percent & $\begin{array}{l}\text { Cumulative } \\
\text { Percent }\end{array}$ \\
\hline \multirow{2}{*}{ Valid } & Male & 99 & 57.2 & 57.2 & 57.2 \\
& Female & 74 & 42.8 & 42.8 & 100.0 \\
& Total & 173 & 100.0 & 100.0 & \\
\hline
\end{tabular}

\subsubsection{Age of the Respondents}

The details about the age of the respondents are given in Table 5 Obviously from the table, the major portion of the respondents consists on young age students $(n=84)$ containing $48 \%$, next are middle age students $(n=73)$ comprising $42 \%$ approximately, while the remaining proportion of the last group $(n=16)$ is about $9 \%$. 
Table 5: Age of the Respondents

\begin{tabular}{llllll}
\hline & & Frequency & Percent & Valid & Cumulative \\
& $18-23$ & 84 & 48.6 & 48.6 & 48.6 \\
\multirow{4}{*}{ Valid } & $24-29$ & 73 & 42.2 & 42.2 & 90.8 \\
& 30 and Above & 16 & 9.2 & 9.2 & 100.0 \\
& Total & 173 & 100.0 & 100.0 & \\
\hline
\end{tabular}

\subsubsection{Monthly Income of the Respondents}

Table 6 gives inside information about the monthly expenses of the students .The students spend monthly (Less than PKR 25,000) nearly 33\%, (25,000-50,000) comprising of nearly $38 \%$, students spend $(51,000-75,000)$ is about $10 \%$, the ratio of the last category (above 75,000) is approximately17\%.

Table 6: Monthly Income of respondents

\begin{tabular}{|c|c|c|c|c|c|}
\hline & & Frequency & Percent & $\begin{array}{l}\text { Valid } \\
\text { Percent }\end{array}$ & $\begin{array}{l}\text { Cumulative } \\
\text { Percent }\end{array}$ \\
\hline \multirow{5}{*}{ Valid } & $\begin{array}{l}\text { LESS than PKR } \\
25000\end{array}$ & 58 & 33.5 & 33.5 & 33.5 \\
\hline & PKR 25000-50000 & 66 & 38.2 & 38.2 & 71.7 \\
\hline & PKR 51000-75000 & 18 & 10.4 & 10.4 & 82.1 \\
\hline & $\begin{array}{l}\text { More than PKR } \\
75000\end{array}$ & 31 & 17.9 & 17.9 & 100.0 \\
\hline & Total & 173 & 100.0 & 100.0 & \\
\hline
\end{tabular}

\subsection{Data Measurement}

\subsubsection{Reliability Analysis}

The Cronbach's alpha value0.806 (table 7) for the construct demonstrated that all questions are interrelated to each other and are internally reliable.

Table 7: Cronbach's Alpha

Cronbach's Alpha

No of Items

0.806

15

\subsubsection{Descriptive Analysis}

Table 8 shows means for all items in the measuring instrument. The overall mean of the consumers' purchasing decision is 3.34, which is higher than 3, representing $67 \%$ of the maximum value (5) on the scale that measures that variable.

\section{Table 8: Descriptive Statistics}

\begin{tabular}{|c|c|c|c|c|}
\hline Measurement Items & $\mathrm{N}$ & Minimum & Maximum & Mean \\
\hline Consumer's Purchasing Decision & 173 & & & $\mathbf{3 . 3 4}$ \\
\hline $\begin{array}{l}\text { I decide to buy something after recognizing my } \\
\text { need }\end{array}$ & 173 & 1 & 5 & 3.62 \\
\hline
\end{tabular}




\begin{tabular}{|c|c|c|c|}
\hline $\begin{array}{l}\text { Advertising in media stimulate my need for } \\
\text { buying something. }\end{array}$ & 1731 & 5 & 3.31 \\
\hline $\begin{array}{l}\text { I collect information before purchasing any } \\
\text { product }\end{array}$ & 1731 & 5 & 3.28 \\
\hline $\begin{array}{l}\text { I always take help from advertising to locate } \\
\text { different product alternatives }\end{array}$ & 1731 & 5 & 3.65 \\
\hline $\begin{array}{l}\text { I believe that personal source of information } \\
\text { (family, friends, and neighbors) is an effective } \\
\text { tool for different opinion about existing and new } \\
\text { products. }\end{array}$ & 1731 & 5 & 3.47 \\
\hline $\begin{array}{l}\text { I believe that media is an effective tool for } \\
\text { different opinions about existing and new } \\
\text { products. }\end{array}$ & 1731 & 5 & 3.63 \\
\hline $\begin{array}{l}\text { Interactions with friends on social media assist } \\
\text { me in evaluating a product. }\end{array}$ & 1731 & 5 & 3.31 \\
\hline $\begin{array}{l}\text { I never purchase a product without handling, or } \\
\text { examining the product. }\end{array}$ & 1731 & 5 & 3.50 \\
\hline I give importance to the quality of a product & 1731 & 5 & 3.52 \\
\hline $\begin{array}{l}\text { The price of products is a good indicator of its } \\
\text { quality. }\end{array}$ & 1731 & 5 & 3.68 \\
\hline Product image influences my product selection. & 1731 & 5 & 3.47 \\
\hline I always stick on to the same brand & 1731 & 5 & 3.47 \\
\hline I buy different brands to get some variety. & 1731 & 5 & 2.45 \\
\hline $\begin{array}{l}\text { I always remain satisfied after using the product } \\
\text { I often change to another product if I had bad }\end{array}$ & 1731 & 5 & 3.43 \\
\hline $\begin{array}{l}\text { experience with the previous one } \\
\text { Valid N (list wise) }\end{array}$ & 1731 & 5 & 2.45 \\
\hline \multicolumn{4}{|c|}{$\begin{array}{l}\text { 4.5 Hypotheses Testing } \\
\text { 4.5.1 Independent Samples T-Test Analysis (Gender) } \\
\text { The table No. } 9 \text { below describes the relationship between gender and purchasing } \\
\text { decision. In this study, to determine the behavior of male and female regarding } \\
\text { purchasing decision and interdependency between independent and dependent } \\
\text { variables, t-test significance and probability value is calculated in table No. } 9 \text {. }\end{array}$} \\
\hline
\end{tabular}


Table 9: Independent Variable (Gender)

Levene's

Test for

Equality of ${ }^{\text {t-test for Equality of Means }}$

Variances

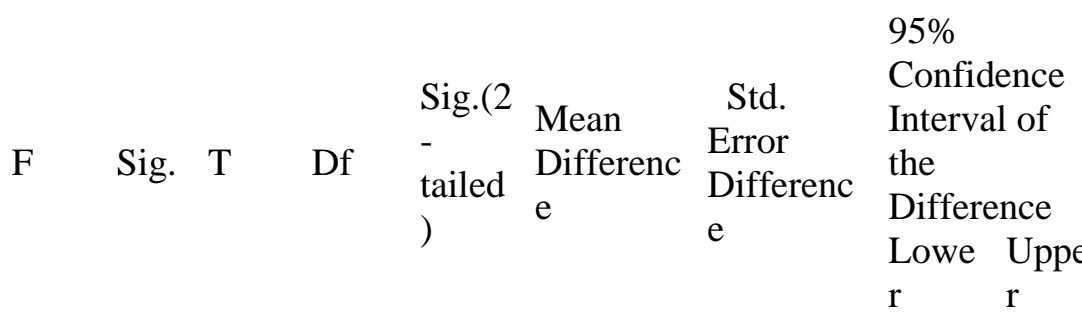

Equal

variance 0.160 .68

s $\quad 7 \quad 3$

$-1.28171$

0.20

$-0.12960$

0.10073

0.32840 .0623

PD

assumed

Equal

variance

s not

$-1.29160 .38 \begin{aligned} & 0.19 \\ & 8\end{aligned}$

$-0.12960$

0.10021

0.32750 .0689

assumed

The table No.10 above describes analysis of perception on primary data collected from students. In order to know the behavior of male and female students regarding purchasing decision the following hypothesis is formulated earlier in this study to test and verify.

\section{Hypothesis 1}

H0: There is no significant difference in purchasing decision of male and female students.

H1: There is a significant difference in purchasing decision of male and female students.

The above table No. 4.6 shows non- statistical differences in consumers purchasing decision due to gender , as $F(170)=0.167$ and $(p>0.05)$. This suggests that there is no difference in purchasing decision of male and female students.

Furthermore, the data analysis reveals that both male and female respond same behavior, perception and attitude towards purchasing decision. It also manifests that, in this study, both male and female shows almost similar respond toward to purchasing decision in all type of consumer goods.

Therefore we accept null hypothesis i.e. $\mathrm{H} 0$ and reject alternate hypothesis $\mathrm{H} 1$.

4.5.2 One-Way ANOVA (Age)

The table No.4.7 below describes the relationship between age and purchasing decision. In this study to determine the behavior of various age groups regarding purchasing decision, and their interdependency between independent and dependent variables ANOVA is used and probability value is calculated in table below. 
Table 10: ANOVA (Age)

\begin{tabular}{llllll}
\hline PD & $\begin{array}{l}\text { Sum of } \\
\text { Squares }\end{array}$ & Df & Mean Square & F & Sig. \\
\hline Between Groups & 1.269 & 2 & .635 & 1.480 & .231 \\
Within Groups & 72.916 & 170 & .429 & & \\
$\quad$ Total & 74.186 & 172 & & & \\
\hline
\end{tabular}

The above table No.11 describes analysis of perception on primary data collected from students. In order to understand the behavior of various age groups students regarding purchasing decision, the following hypothesis is formulated earlier to test and verify.

\section{Hypothesis 2}

H0: There is no significant difference in purchasing decision of different age groups.

$\mathrm{H} 1$ : There is a significant difference in purchasing decision of different age groups.

The table No.4.7 above states non-statistical differences in consumers purchasing decision due to age, as $\mathrm{F}(170)=1.480$ ( $\mathrm{p}>0.05$ ). This suggests that there is no difference in purchasing decision of different age group categories of students.

Furthermore, the data analysis reveals that consumers of all age groups respond same behavior, perception and attitude towards purchasing decision. It also manifest that all age groups appeared to be somehow similar in terms of their purchasing decision in all type of consumer goods.

Therefore we accept null hypothesis i.e. $\mathrm{H} 0$ and reject alternate hypothesis $\mathrm{H} 1$.

\subsubsection{One-Way ANOVA (Income)}

The table No.4.8 below describes the relationship between monthly income of students that they spend and its relationship with their purchase decision. To determine the behavior of various income groups regarding their purchasing decision, and their interdependency ANOVA is used and probability value is calculated.

Table 11: ANOVA (Income)

\begin{tabular}{llllll}
\hline PD & Sum of Squares & Df & Mean Square & F & Sig. \\
\hline Between Groups & 6.010 & 3 & 2.003 & 4.966 & 0.003 \\
Within Groups & 68.176 & 169 & 0.403 & & \\
Total & 74.186 & 172 & & & \\
\hline
\end{tabular}

The table No.12 above describes analysis of perception of various income groups that they spent on purchasing goods and services. The primary data collected from students is analyzed, in order to understand the behavior of various income groups regarding purchasing decision. The following hypothesis is formulated earlier in study is tested for verification. 


\section{Hypothesis 3}

H0: There is no significant difference in purchasing decision of different monthly income groups of students.

H1: There is a significant difference in purchasing decision of different monthly income groups of students. The table No.4.8 states statistical differences in consumers purchasing decision due to different income levels, as $F(170)=4.966$ and $(\mathrm{p}=0.003)$.This suggests that income is likely to have an effect on the purchasing decision . Furthermore, the data analysis reveals that consumers of different monthly incomes respond different behavior, perception and attitude towards purchasing decision. It also shows that all income groups appeared to be different in terms of their purchasing decision in all types of consumer goods.

Therefore we accept alternate hypothesis i.e. H1 and reject null hypothesis H0.

\section{Conclusion}

The aim of this study was to examine the impact of demographic factors such as gender, age and income on consumers' purchasing decision. Results of the empirical study indicated that there was no difference in purchasing decision process of male and female, they recognize their need internally and externally through TV advertising. Both male and female groups search information via TV advertising, consult family members, friends including social media friends. They all give importance to the brand image and shop keeper view. Both seek variety, and feel the same degree of satisfaction and switch to another brand whenever they have bad experience with the current one. Through empirical study similar results have been found for various age groups of consumers (students).It means like gender age also has no significant impact on purchasing decision. There is a difference in purchasing decision of the students of different income levels. Students with high monthly income are not price sensitive and consider quality when they evaluate and purchase products as compared to students with low monthly income.

\subsection{Recommendations}

After the thorough study of the results the following recommendations are made for business organizations.

- Both male and female use the same sources for information reception and evaluation of Product alternatives therefore marketing companies must made similar advertising strategies for both male and female consumers.

- The empirical result shows that all age groups display almost similar behavior while making purchasing decision, therefore companies must keep in mind the commonality of various age groups while devising marketing and advertising strategies.

- Companies must segment market on the bases of income variables as different income groups of consumers respond differently to the marketing offers.

- Today all segments of society use social media (facebook etc), therefore businesses must advertise their products on social media to inform remind and persuade the people.

- As the empirical result shows that the consumers give importance to the shopkeeper view regarding product selection, therefore companies have to adopt push promotion strategy for shopkeepers to recommend the company product and in return get rewards. 
- Brand image may not be created easily in an over communicated and saturated market therefore companies must advertise their brands heavily on distinctive features to make positive image in consumers' mind.

- The companies through communication have to assure the consumers that their choice is good to influence their repeated purchases.

- The cost of attracting new customers is high than to retain current costumers therefore companies must develop programs to retain them.

\subsection{Limitations and Directions for Future Research}

For future studies, it is recommended to have a larger sample and to create smaller groups when analyzing data. Furthermore in this study the relationship of demographic factors with general purchasing decision process has been explored however it would be wise to investigate more specific purchasing decision process for more specific product and brand. Furthermore 50 plus years old people must be included in future studies to get more authentic results regarding the relationship of age and purchasing decision. Future studies could also consider illiterate people to be included in the study to draw a clear line between the purchasing decisions of illiterate and educated consumers.

\section{References}

Bakshi, S. (2012). Impact of gender on consumer purchase behavior. Journal of Research in Commerce and Management, 1(9), 1-8.

Bryman, A., \& Bell, E. (2003). Breaking down the quantitative/qualitative divide. Business Research Methods, 465-478.

Dhanapal, S., Subramaniam, T., \& Vashu, D. (2013). Factors affecting job satisfaction among academicians: A comparative study between gender and generations. International Journal of Management Excellence, 2(1), 128-139.

Dotson, M. J., \& Hyatt, E. M. (2001). Sales promotion preferences: A demographic analysis. Marketing Advances in Pedagogy, Process, and Philosophy, Stillwater, OK: Society for Marketing Advances, 29-32.

East, R., Harris, P., Willson, G., \& Lomax, W. (1995). Loyalty to supermarkets. International Review of Retail, Distribution and Consumer Research, 5(1), 99-109.

Gill, S., Stockard, J., Johnson, M., \& Williams, S. (1987). Measuring gender differences: The expressive dimension and critique of androgyny scales. Sex roles, $17(7-8), 375-400$.

Glass, G. V., \& Hopkins, K. D. (1984). Inferences about the difference between means. In Statistical methods in education and psychology (pp. 249-253). PrenticeHall, Inc, Englewood Cliffs, NJ.

Henthorne, T. L., LaTour, M. S., \& Hudson, T. W. (1997). Japanese couples' marital roles in stages of product purchase decision making. International Marketing Review, 14(1), 39-58.

Homburg, C., \& Giering, A. (2001). Personal characteristics as moderators of the relationship between customer satisfaction and loyalty-an empirical analysis. Psychology \& Marketing, 18(1), 43-66. 
Johnson, M. M. (1990). Age differences in decision making: A process methodology for examining strategic information processing. Journal of Gerontology, 45(2), P75P78.

Kakiza, C. (2015). Factors affecting purchasing decisions of the Consumers: A case of Kinondoni district (Dar es salaam)(Doctoral dissertation, Mzumbe University).

Khan, A. H., Nawaz, M. M., Aleem, M., \& Hamed, W. (2012). Impact of job satisfaction on employee performance: An empirical study of autonomous Medical Institutions of Pakistan. African Journal of Business Management, 6(7), 2697-2705.

Kombo, D. K., \& Tromp, D. L. (2006). Proposal and thesis writing: An introduction. Nairobi: Paulines Publications Africa, 5, 814-30.

Kotler, P., \& Armstrong, G. (2001). Principles of Marketing: 3th.prentice-hall, p:143 Lambert-Pandraud, R., \& Laurent, G. (2010). Impact of age on brand choice. the Aging Consumer: perspectives from psychology and Economics, 191-208.

Lambert-Pandraud, R., Laurent, G., \& Lapersonne, E. (2005). Repeat purchasing of new automobiles by older consumers: empirical evidence and interpretations. Journal of Marketing, 69(2), 97-113.

Livette, M. (2007). Influencer and other "buying" roles in the decision-making process of retirement housing purchasers. Property Management, 25(3), 242-256.

Mitchell, V. W., \& Walsh, G. (2004). Gender differences in German consumer decision making styles. Journal of Consumer Behavior: An International Research Review, 3(4), 331-346.

Plabdaeng, C. (2010). Gender influence on purchase intention-the case study of Thailand. Master in Business Administration Thesis, Universiti Sains Malaysia

Pratap, A. (2017). Effects of Demographic Factors on Consumer Behavior: Age, sex, Income and Education

Saleh, M. A. H., Alothman, B., \& Alhoshan, L. (2013). Impact of Gender, Age and Income on Consumers' Purchasing Responsiveness to Free-Product Samples. Research Journal of International Studies, 83

Schiffman, L. G., \& Kanuk, L. L. (2012). Consumer behavior. Sekaran, U. (2003). Research methods for business. Hoboken.

Sharma, M., \& Antil, S. (2013). Effect of consumer response on sales promotion in organized food retailing. In Tenth AIMS International Conference on Management (Vol. 6, No. 9, pp. 2443-2448).

Wood, S., Hanoch, Y., \& Barnes, A. et al. (2011). Numeracy and Medicare part D: the importance of choice and literacy for numbers in optimizing decision making for Medicare's prescription drug program. Psychol Aging. 26:295-307. [PubMed: 21553984] 